\title{
Retrofit Sistem Pencampuran 2 Fluida Beda Warna Menggunakan Mikrokontroler
}

\author{
1Triana, Y., ${ }^{2}$ Rosianah. A., ${ }^{3}$ Hersaputri, M., ${ }^{4}$ Hadisupadmo, S. \\ 1,2 Program Studi D3 Metrologi Dan Instrumentasi Fakultas Teknologi Industri Institut Teknologi Bandung \\ 3 Pusat Tekonologi Instrumentasi dan Otomasi, ITB \\ 4 Program Studi Teknik Fisika, ITB \\ megarini@instrument.itb.ac.id
}

\begin{abstract}
Abstrak
Sejak abad ke-20 inovasi teknologi instrumentasi dan sistem kontrol berkembang dengan sangat cepat. Hal ini diikuti dengan berkembangnya karakter masyarakat yang memiliki mobilitas yang semakin tinggi. Masyarakat menginginkan layanan otomatis, mudah, fleksibel, efisien baik dalam biaya maupun waktu serta aman saat digunakan. Di insdustri saat ini terlebih minyak, cat, lem atau minuman telah dikembangkan proses otomasi pencampuran warna. Proses ini dapat menghasilkan percampuran warna dan kekentalan.

Pada penelitian ini, dilakukan simulasi kontrol otomasi pencampuran fluida beda warna (Simulator Fluid-mixing) dengan menggunakan mikrokontroler Program Arduino. Simulator fluid-mixing ini merupakan pengembangan simulator yang pernah dibuat (Dr. Eng. Edi Leksono, 2005). Program Arduino dapat diatur oleh operator dan simulator dapat menghasilkan campuran fluida warna. Otomasi dari simulator fluid-mixing dirancang untuk memudahkan operator dalam melakukan simulasi. Pencampuran fluida dapat dilakukan untuk 2 warna dengan jenis fluida yang sama yaitu air. Terdapat 2 saklar sebagai pilihan program, program 1 (25\% dan $50 \%)$ dan program 2 (50\% dan 50\%).

Perancangan simulator fluid-mixing dapat digunakan oleh Teknik Fisika ITB sebagai alat pembelajaran mahasiswa dalam melakukan proses simulator untuk pencampuran fluida beda warna.

kata kunci : Bahan Bakar Minyak, Principle Component Analysis, Back Propagation Neuron Networks.
\end{abstract}

\section{Pendahuluan}

Bahan Bakar Minyak (BBM) merupakan komoditas Sejak abad ke-20 inovasi di dalam teknologi instrumentasi dan sistem kontrol berkembang dengan sangat cepat. Hal ini diikuti dengan berkembangnya karakter masyarakat yang memiliki mobilitas semakin tinggi. Masyarakat menginginkan layanan otomatis, mudah, fleksibel, efisien baik dalam biaya maupun waktu serta aman saat digunakan. Dalam insdustri saat ini terlebih minyak, cat, lem atau minuman telah dikembangkan proses otomasi pencampuran warna. Proses ini dapat menghasilkan percampuran warna dan kekentalan. Pada penelitian ini akan dilakukan perancangan simulator. Simulator ini pernah dibuat (Dr. Eng. Edi Leksono, 2005), sebelumnya simulator menggunakan mikrokontroler PLC. Pada penelitian ini dilakukan simulasi kontrol otomasi pencampuran fluida beda warna dengan menggunakan mikrokontroler Program Arduino yang dapat diatur oleh operator dan simulator dapat menghasilkan campuran fluida dengan lebih praktis yang selanjutnya disebut simulator fluidmixing. Simulator ini nantinya akan digunakan oleh Teknik Fisika ITB sebagai alat pembelajaran bagi mahasiswanya. Teknik Fisika ITB belum memiliki simulator untuk pencampuran fluida, karena untuk simulator fluid-mixing yang ada dipasaran dijual dengan harga yang relatif mahal. Oleh karena itu dibuatlah simulator fluid-mixing yang relatif lebih murah.

Tujuan dari penelitian ini adalah untuk mengembangkan alat simulasi kontrol otomasi pencampuran warna, memudahkan user dalam menggunakan alat simulasi kontrol otomasi pencampuran warna serta sebagai simulator yang digunakan mahasiswa untuk alat pembelajaran

\section{Perancangan Sistem}

Simulator fluid-mixing merupakan sebuah perangkat pelatihan yang menggunakan instrumentasi control untuk memudahkan penggunaan pada alat simulasi. Pada Gambar 1. adalah skematik dari Simulator fluid-mixing yang merupakan gambar rancangan yang menjelasakan proses yang terjadi pada pencampuran fluida. Sistem keseluruhan yang berhasil dibangun dapat dilihat pada Gambar 2. 


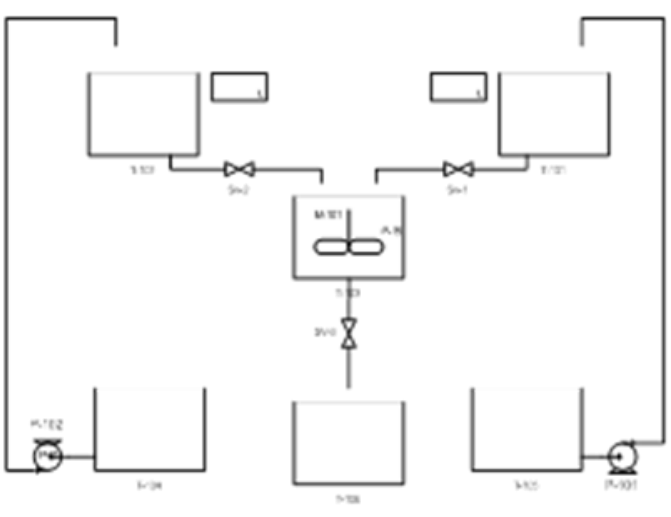

Gambar 1. Skematik Simulator Fluid-Mixing

Pada Gambar 1 menjelaskan arah aliran fluida dari Tangki Resevoir 4 dan 5 (T-104 dan T-105) sampai Tangki Penyimpanan Hasil Akhir 6 (T-106). Fluida dipompa hingga mencapai volume tertentu di Tangki Bahan (T-101) dan 2 (T-102), kemudian dialirkan melalui solenoid valve 1 (SV-1) dan solenoid valve 2 (SV-2) menuju Tangki Penampung Hasil Pencampuran 3 (T-103). Pada Tangki Penampung Hasil Pencampuran fluida diaduk atau dimix beberapa saat baru setelah itu dialirkan kembali melewati solenoid valve 3 (SV-3) menuju tangki akhir 6 (T-106).

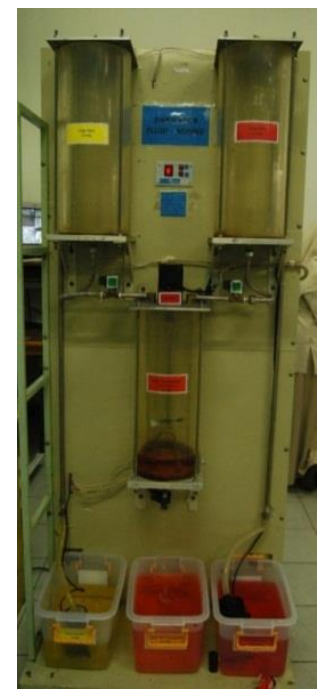

Gambar 2. SimulatorFluid-Mixing

Perancangan simulator fluid-mixing dimulai dari solenoid valve sampai dengan komponenkomponen yang lain akan merujuk pada spesifikasi dari simulator fluid-mixing ini. Dengan bukaan solenoid valve yang sama, akan membuat keluaran fluida menjadi stabil sehingga dapat diketahui berapa waktu yang dibutuhkan. Berikut adalah penjelasan lebih lanjut mengenai simulator fluid-mixing adalah sebagai berikut :

\section{Solenoid Valve}

Komponen ini merupakan komponen penentu pemilihan komponen yang lain. Tujuan dari penelitian ini adalah mengembangkan alat simulasi kontrol otomasi, oleh karena itu dipilih solenoid valve ini. Hal ini disebabkan karena solenoid valve adalah valve yang mempunyai spesifikasi khusus. Pemilihan komponen selanjutnya ditentukan oleh pemilihan awal dari tipe solenoid valve ini, tipe solenoid valve yang digunakan adalah solenoid valve VX2130S untuk tipe fluida air. Solenoid valve yang digunakan dalam penelitian ini dapat dilihat pada Gambar 3.

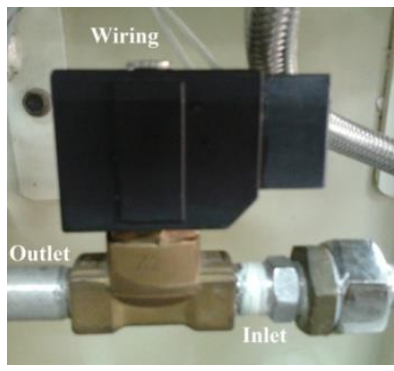

\section{Gambar 3. Solenoid Valve VX2130S}

Dalam penelitian ini solenoid valve, berfungsi sebagai valve otomatis yang bekerja mengalirkan fluida dari tangki level switch 1 (T-101) dan 2 (T102) menuju tangki pencampuran (T-103) dan dari tangki pemcampuran 3 (T-103) menuju tangki akhir 6 (T-106). Gerak dari solenoid valve diatur melalui Program Arduino dengan bukaan valve full open dan full close. Karena bukaan dari solenoid valve full open dan full close, menggunakan pipa dari bahan plat anti karat dengan lingkaran $1 / 2$ inch, aliran dari solenoid valve ini stabil. Hal ini memudahkan dalam pembuatan program pada Arduino.

\section{Pompa}

Pompa yang digunakan ada dua buah pompa 1 ( $\mathrm{P}$ 101) dan pompa 2 (P-102) dengan tipe yang berbeda. Setelah dilakukan percobaan, meskipun kecepatan aliran fluida tidak sama namun spesifikasi dari kedua pompa ini tidak jauh berbeda sehingga masih dapat digunakan. Pompa yang digunakan dapat dilihat pada Gambar 4 dan Gambar 5. 
Seminar Nasional Instrumentasi, Kontrol dan Otomasi (SNIKO) 2015 Bandung, Indonesia, 10-11 Desember 2015

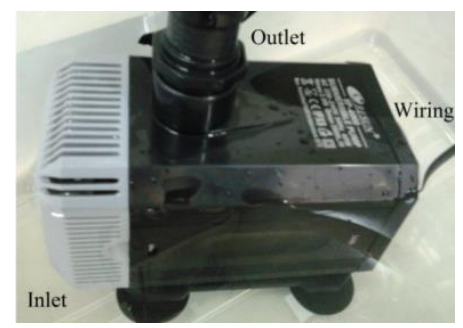

Gambar 4. Pompa 1 (P-101)

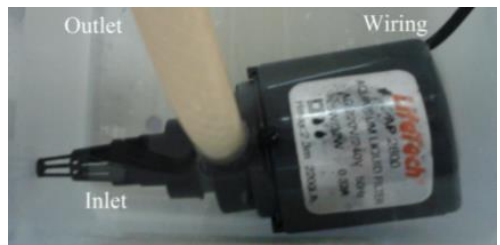

Gambar 5. Pompa 2 (P-102)

Pompa 1 (P-101) berfungsi memindahkan fluida dari Tangki Reservoir (T-105) menuju Tangki Bahan (T-101) melalui pipa stainless yang berdiamater $1 / 2$ inch. Sedangkan Pompa 2 (P-102) yang berfungsi memindahkan fluida dari Tangki Reservoir (T-104) menuju Tangki Bahan (T-102), juga sama halnya dengan Pompa 1, memindahkan melalui pipa berdiameter $1 / 2$ inch.

\section{Mixer}

Mixer disini sebenarya bukanlah mixer yang biasa dipakai untuk membuat kue, tetapi mixer disini adalah motor/dinamo yang dipasangkan balingbaling, sehingga motor tersebut berfungsi sebagai mixer pengaduk fluida. Gambar mixer dapat dilihat pada Gambar 6.

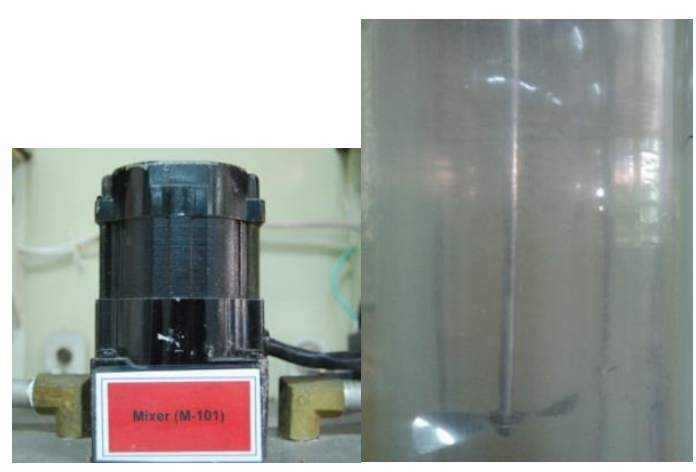

Gambar 6 Mixer (M-101)

Mixer (M-101) berfungsi mengaduk fluida yang dilalirkan dari Tangki Bahan (T-101) dan (T-102) ke Tangki Penampung Hasil Pencampuran (T-103).
Gambar a. memperlihatkan mixer bagian tampak atas yang terdapat motor. Sedangkan Gambar b. memperlihatkan mixer bagian bawah atau dalam Tangki Penampung Hasil Pencampuran (T-103) yang berbentuk baling-baling.

\section{Tangki}

Pada alat simulator ini, terdapat 4 jenis Tangki yang digunakan dengan total keseluruhan 6 tangki.

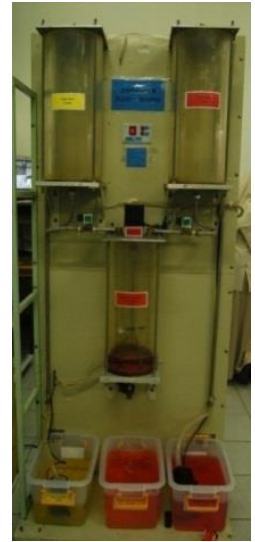

Gambar 7. Simulator fluid-mixing

Tangki-tangki yang terdapat dalam alat ini adalah :

1.Tangki Reservoir (T-104) dan (T-105)

2.Tangki Bahan (T-101) dan (T-102)

3.Tangki Penampung Hasil Pencampuran (T-103)

4.Tangki Penyimpanan Hasil Akhir (T-106)

Penjelasan mengenai jenis-jenis yang terdapat pada simulator fluid-mixing adalah sebagai berikut:

Tangki Reservoir (T-104) dan (T-105) berfungsi sebagai penyimpanan awal.

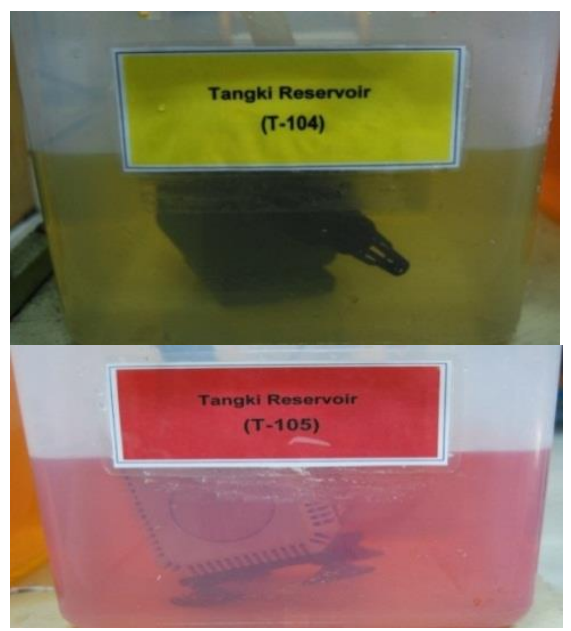


Seminar Nasional Instrumentasi, Kontrol dan Otomasi (SNIKO) 2015 Bandung, Indonesia, 10-11 Desember 2015

Gambar 8. Tangki Reservoir pada simulator fluid-mixing a. Reservoir Kuning (T-104) b. Reservoir Merah (T-105)

Tangki Bahan (T-101) dan (T-102) berfungsi sebagai Tangki penyimpanan sebelum dicampurkan dan disimpan di Tangki Penyimpanan Hasil Akhir (T-106).

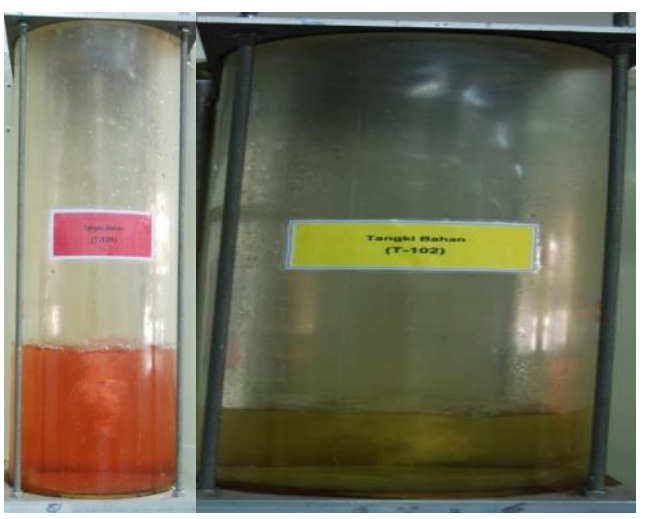

Gambar 9. Tangki Bahan pada simulator fluid-mixing a. Tangki Bahan (T-101) b. Tangki bahan (T-102)

Tangki Pencampuran (T-103) berfungsi sebagai Tangki yang digunakan ketika 2 fluida yang berbeda warna dari Tangki (T-102) dan (T-102) untuk diaduk oleh mixer (M-101).

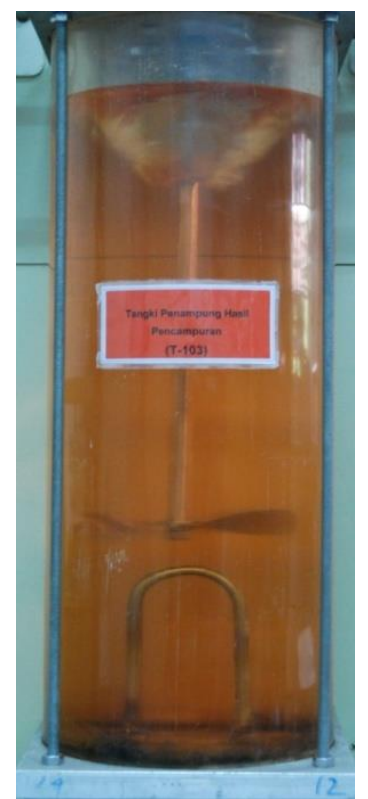

Gambar 10. Tangki Penampung Hasil Pencampuran (T103

Tangki Penyimpanan Hasil Akhir (T-106) berfungsi sebagai Tangki Penyimpanan hasil 2 fluida warna yang sudah diaduk oleh mixer yang dipindahkan dari Tangki (T-103).

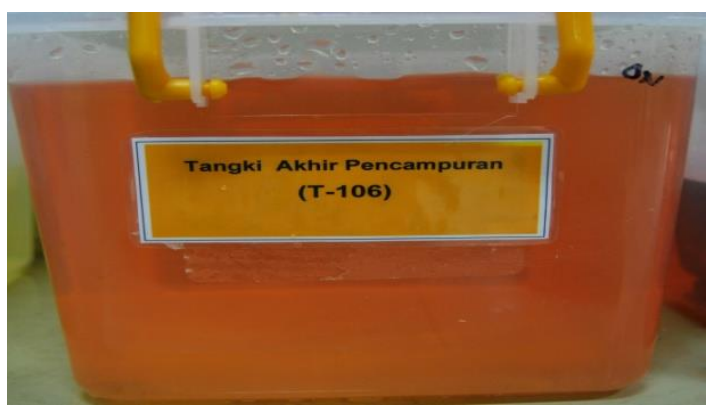

Gambar 11. Tangki Penyimpanan Hasil Akhir (T-106)

\section{Sensor Level}

Sensor yang digunakan dalam alat ini, adalah sensor deepstick, terdiri dari 2 buah batang berbahan stainless, batang satu berfungsi sebagai GND dan yang satu befungsi sebagai sensor pendeteksinya. Ketika air yang disalurkan Pompa (P-101) dan (P-102) dari Tangki Reservoir (T-104) dan (T-105) menuju Tangki Bahan (T-102) dan (T102) dan air tersebut sudah mencapai ketinggian atau volume yang ditentukan. Maka sensor akan mendeteksi dan memberikan input kepada Arduino untuk menghentikan Pompa (P-101) dan (P-102).

\section{Proses Pada Simulator fluid-mixing}

Simulator fluid-mixing yang dirancang merupakan sebuah alat simulasi untuk pencampuran fluida beda warna dengan kontrol otomasi. Proses yang terjadi pada simulator fluid-mixing bermula dari diberikannya input saklar (1 atau 2) yang akan memberikan informasi kepada Arduino untuk memberikan perintah berupa lama bukaan dari keluaran solenoid valve. Setelah input saklar diberikan, fluida berupa air berwarna yang tertampung pada Tangki Resevoir (T-104 dan T105), air tersebut diambil dan didorong dialirkan menggunakan Pompa (P-101 dan P-102) menuju Tangki Bahan (T-101 dan T-102). Tangki Bahan 1 (T-101) berisi air dengan warna merah sedangkan untuk Tangki Bahan 2 (T-102) berisi air dengan warna kuning. Dalam tangki bahan terdapat sensor level, dengan ketinggian tertentu dan air menyentuh sensor tersebut maka sensor akan mendeteksi dan memberikan input kepada Arduino untuk menghentikan Pompa (P-101) dan (P-102). Disaat yang bersamaan Arduino juga mengirimkan perintah untuk membuka Solenoid valve (SV-1 dan SV-2).

Diawal perintah, terdapat 2 perintah yang akan membedakan lama bukaan dari solenoid valve. Perintah pertama yaitu $25 \%$ dan $50 \%$, artinya pada tangki bahan 1 (T-101) akan mengalirkan fluida 1/2 dari volume maksimumnya atau $25 \%$ dari volume total pada Tangki Penampung Hasil Pencampuran (T-103) dan pada Tangki Bahan 2 (T-102) akan 
mengalirkan semua fluida yang ada pada tangki bahan tersebut atau $50 \%$ dari volume totalnya. Untuk perintah 2 yaitu 50\% dan 50\%, artinya pada Tangki Bahan 1 (T-101) dan Tangki Bahan 2 (T102) akan mengalirkan semua fluida yang ada pada tangki bahan atau 50\% dari volume total Tangki Penampung Hasil Pencampuran (T-103). Kemudian, setelah SV sudah tertutup secara mixer akan berputar dengan lama putaran yang sudah ditentukan. Ketika warna sudah tercampur merata, dalam hitungan detik Solenoid valve 3 (SV3) akan membuka dan mengalirkan fluida yang ada didalam Tangki Penampung Hasil Pencampuran (T-103) menuju Tangki Penyimpanan Hasil Akhir (T-106).

Sistem yang dirancang pada Arduino adalah keseluruhan sistem dari simulator fluid-mixing yang meliputi fungsi untuk mengatur sistem kerja dari pompa, pengontrolan relay, solenoid valve dan mixer.

Dibawah ini adalah gambar skematik dari sistem simulator fluid-mixing mulai dari masukan tegangan menuju alat-alat yang digunakan seperti pompa, mixer, solenoid valve.

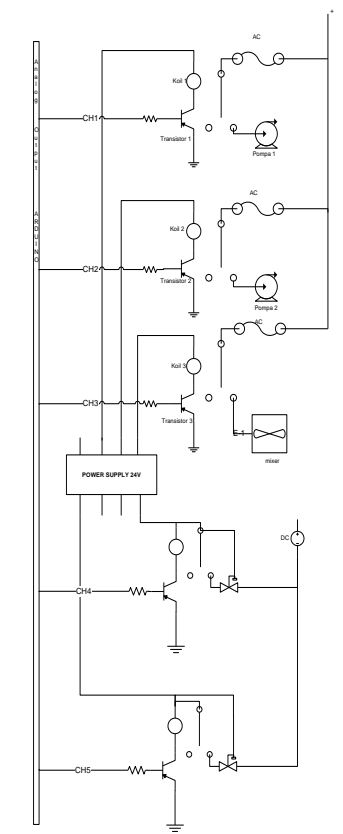

Gambar 12. Skematik rangkaian simulator fluid-mixing

Sedangkan untuk diagram alir dari sistem program yang dibuat pada Arduino dengan program dari Arduino pada lampiran A :

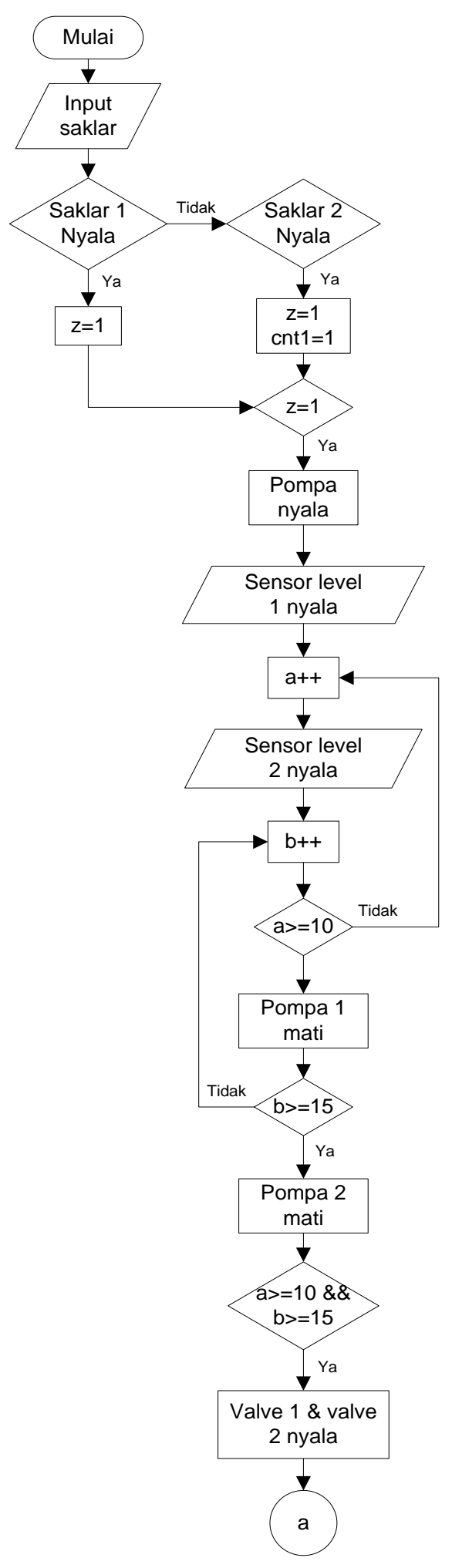

Gambar 13. Diagram alir Arduino 
Seminar Nasional Instrumentasi, Kontrol dan Otomasi (SNIKO) 2015 Bandung, Indonesia, 10-11 Desember 2015

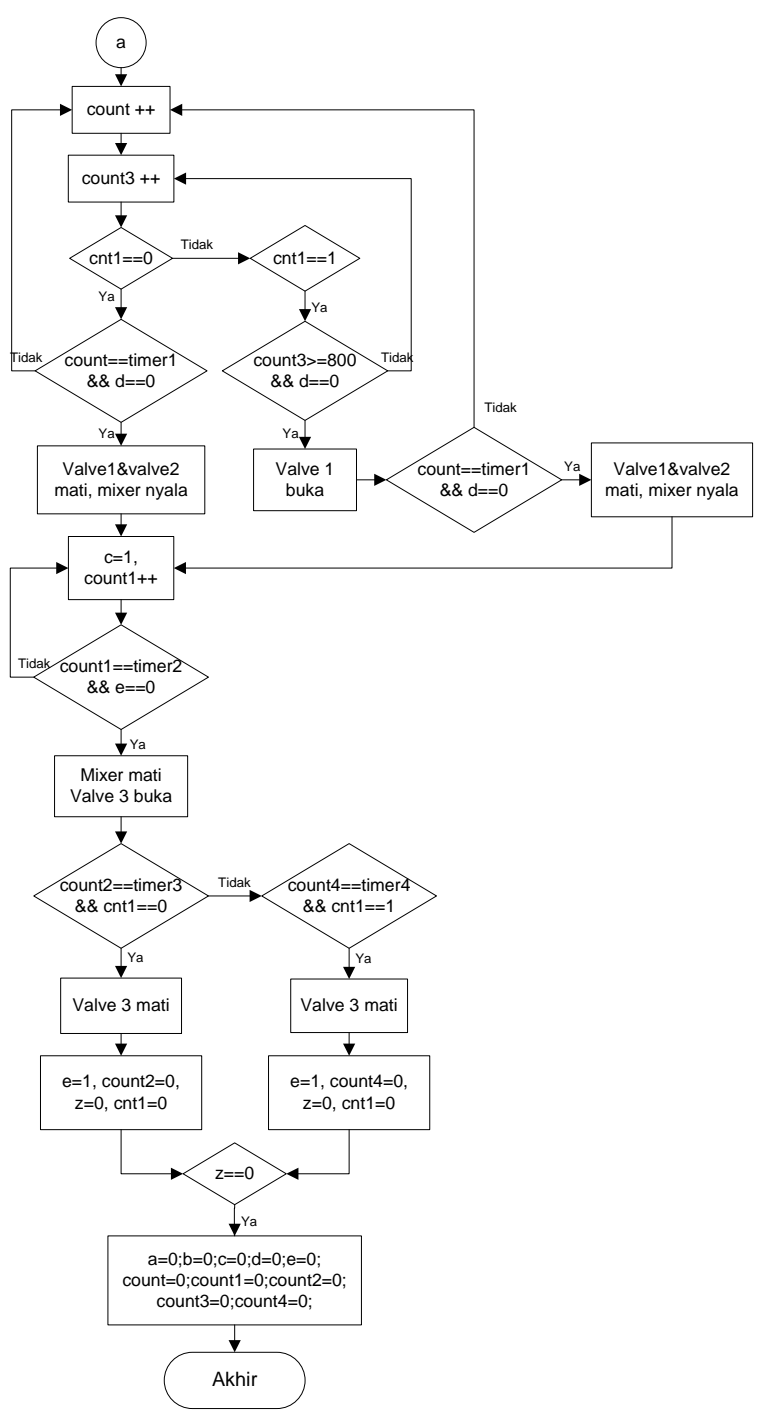

Gambar 14. Diagram alir Arduino (lanjutan)

\section{Implementasi Sistem}

\section{Persiapan Hardware}

Sambungkan kabel terminal yang terpasang pada papan alat ke sumber tegangan 220v-230v. Kemudian setelah kabel terminal telah terpasang, hubungkan steker yang terhubung dengan MCB (miniatur circuit breaker) ke terminal steker yang terpasang pada papan simulator fluid-mixing atau dapat dilihat pada Gambar 15.

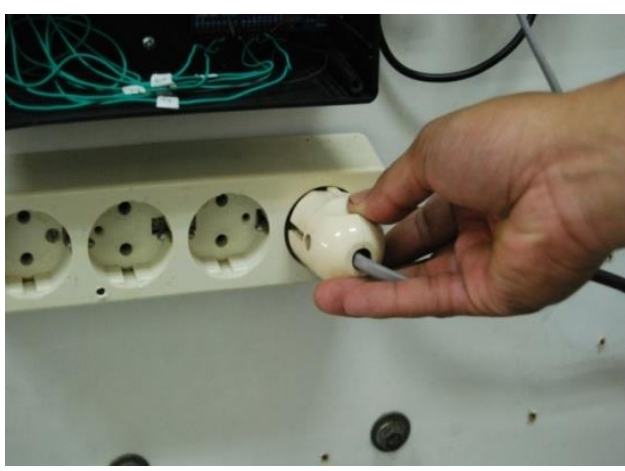

Gambar 15. Steker MCB ke terminal steker

Rubah posisi MCB pada posisi ON.

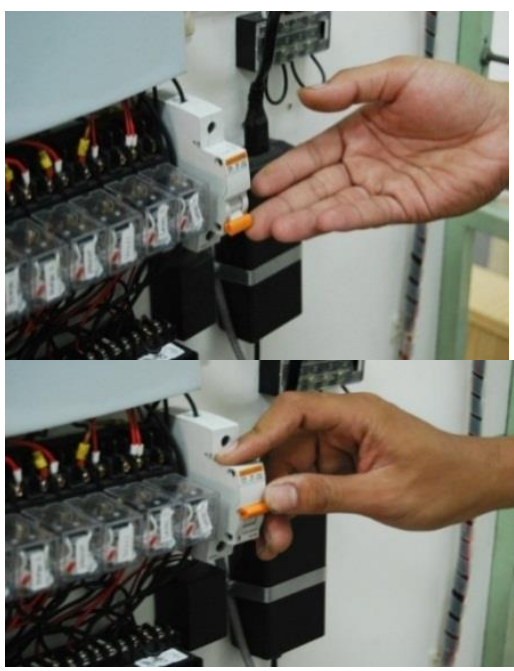

Gambar 16.. MCB (Mini Circuit Breaker)

Ketika alat sudah dipastikan mendapatkan arus dan tegangan dan MCB sudah posisi ON. Setelah itu rubah atau tekan saklar utama dalam keadaan ON yang terdapat pada bagian depan simulator fluid-mixing. 


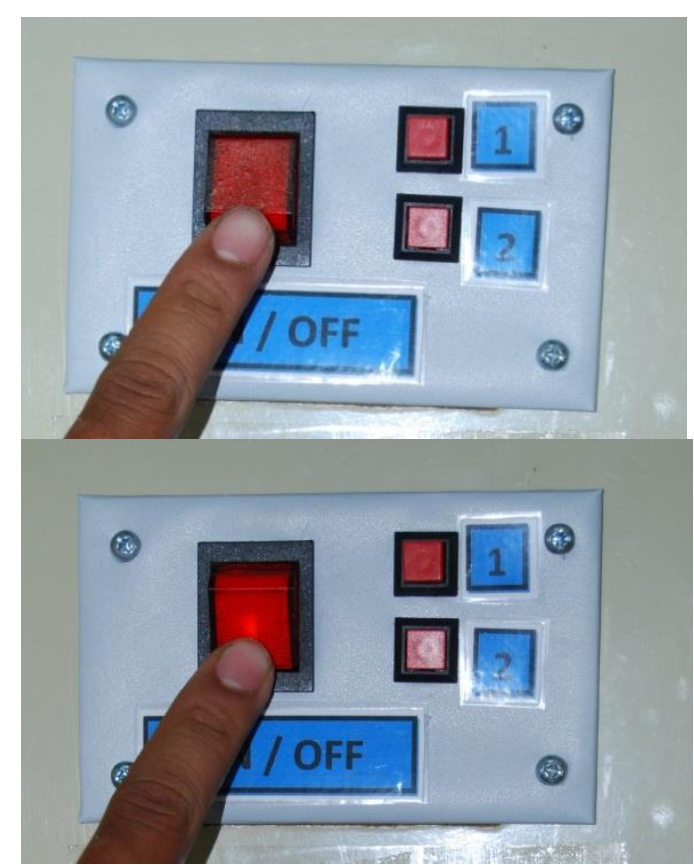

\section{Gambar 17. Saklar Utama pada simulator fluid-mixing}

Setelah MCB dan saklar utama sudah dalam posisi ON, maka alat siap untuk diuji atau digunakan. Sebelumnya untuk memulai menjalankan alat simulator, pilih saklar kecil yang terdapat pada bagian depan simulator fluid-mixing. Kedua saklar kecil adalah saklar pilihan perintah program yang akan menggerakkan alat simulator. Pilih salah satu saklar kecil tersebut, sebagai contoh dipilih saklar kecil pada bagian bawah seperti terlihat pada Gambar 18.

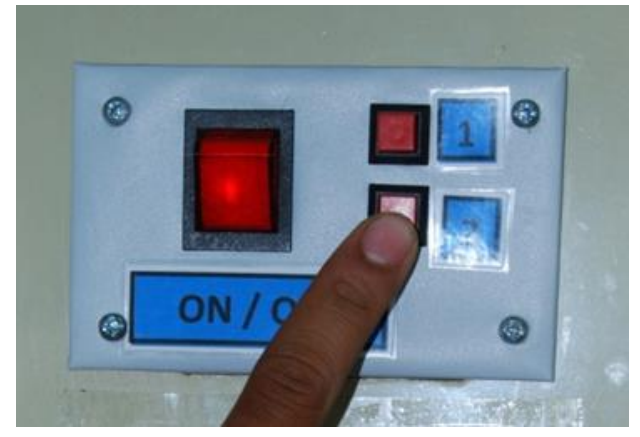

Gambar 18. Saklar utama dan saklar program 1 \& 2

\section{Running Program}

Pada percobaan dalam verialitian ini, diambil contoh program 2 yaitu $50 \%$ dan . $50 \%$. Program ini artinya, pada Tangki Bahan 1 (T-101) dan Tangki Bahan 2 (T-102) akan mengalirkan semua fluida warna yang ada pada Tangki Bahan atau 50\% dari volume total Tangki Penampung Hasil Pencampuran (T-103). Perbedaan dengan program
1 adalah pada Tangki Bahan 1 (T-101) akan mengalirkan fluida warna hanya $1 / 2$ dari volume maksimumnya atau $25 \%$ dari volume total pada Tangki Penampung Hasil Pencampuran (T-103) dan pada Tangki Bahan 2 (T-102) akan mengalirkan semua fluida yang ada pada Tangki Bahan tersebut atau 50\% dari volume totalnya.

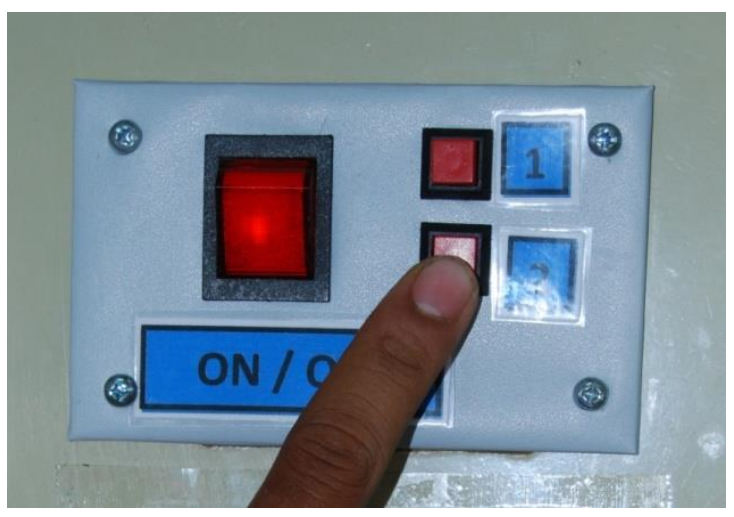

Gambar 19. Saklar 2 (50\% dan 50\%)

Setelah memilih program 2 untuk dijalankan, komponen pertama yang bekerja ialah Pompa 1 (P-101) dan Pompa 2 (P-102), memindahkan fluida dari Tangki Reservoir (T-104) dan (T-105) menuju Tangki Bahan (T-101) dan (T-102) melalui pipa stainless yang berdiamater $1 / 2$ inch.

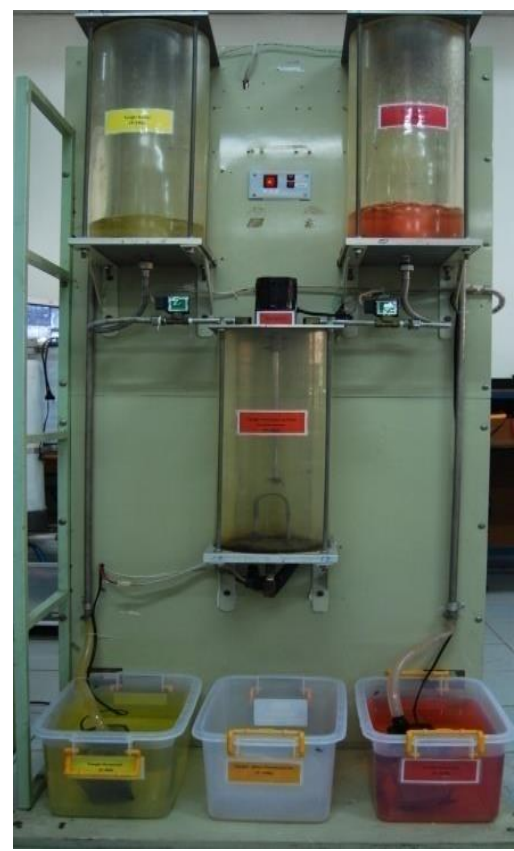

Gambar 20. Proses aliran fluida warna pada Simulator fluid-mixing

Pompa 1 (P-101) dan Pompa 2 (P-102) akan berhenti bekerja setelah fluida mengisi Tangki Bahan (T-101) dan (T-102) dan menyentuh sensor level, dapat dilihat pada Gambar 21. dan tampilan relay seperti pada Gambar 22. 
Seminar Nasional Instrumentasi, Kontrol dan Otomasi (SNIKO) 2015 Bandung, Indonesia, 10-11 Desember 2015

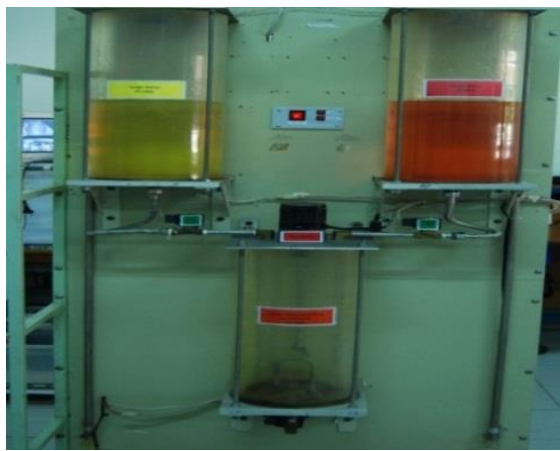

Gambar 21. Tangki Bahan Terisi

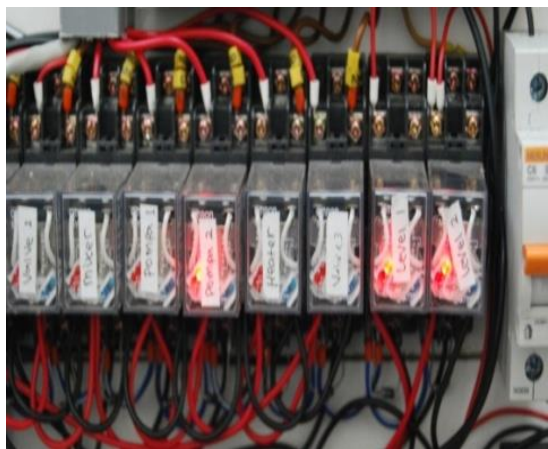

Gambar 22. Relay Sensor Level ON

Setelah sensor level bekerja dengan menyentuh sensor level tersebut, maka solenoid valve (SV-1) dan (SV-2) secara otomatis akan membuka. Valve ini membuka untuk mengalirkan fluida dari Tangki Bahan (T-101) dan (T-102) ke Tangki Penampung Hasil Pencampuran (T-103). Tampilan relay seperti pada Gambar 23.

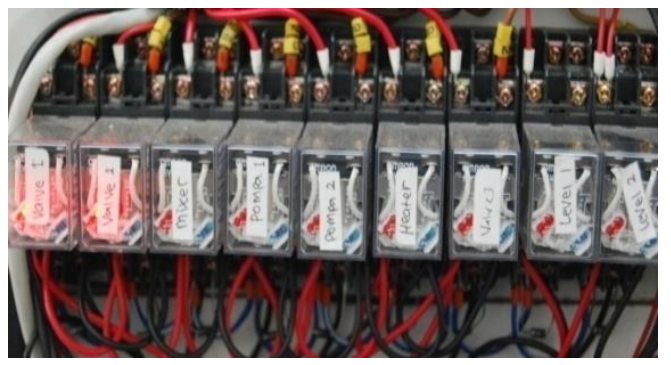

Gambar 23. Relay solenoid valve $1 \& 2$ ON

Setelah semua fluida dari Tangki Bahan (T-101) dan (T-102) habis dan mengisi penuh Tangki Penampung Hasil Pencampuran (T-103), solenoid valve (SV-1) dan (SV-2) akan berhenti bekerja. Kemudian mixer akan bekerja, bekerjanya mixer berfungsi sebagai pengaduk kedua fluida yang berbeda warna. Dapat dilihat pada Gambar 10. dengan kondisi relay mixer ON pada Gambar 11.

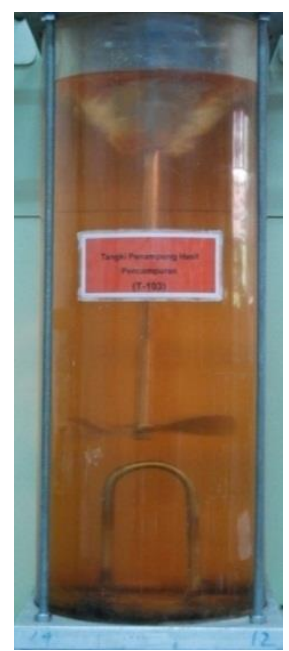

Gambar 24. Tangki Penampung Hasil Pencampuran (T103)

terisi penuh dan diaduk oleh mixer.

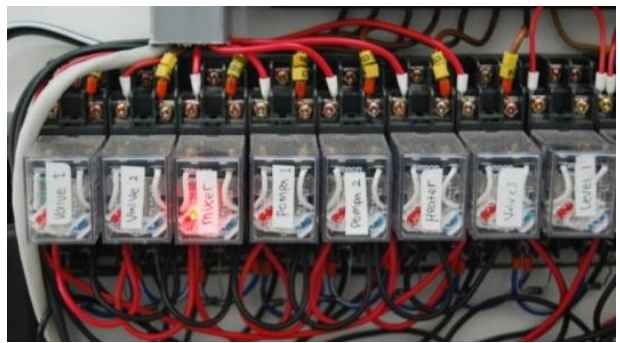

Gambar 25. Relay mixer ON

Selanjutnya setelah mixer berhenti mengaduk campuran fluida warna, maka dalam 3 detik Relay solenoid valve (SV-3) akan ON. Solenoid valve (SV3) akan bekerja sehingga membuka dan mengalirkan hasil campuran 2 fluida warna yang sudah diaduk dan tercampur oleh mixer dari Tangki Penampung Hasil Pencampuran (T-103) menuju Tangki Penyimpanan Hasil Akhir (T-106) hingga mengisi penuh Tangki Penyimpanan Hasil Akhir (T-106). Seperti yang terlihat pada Gambar 26.

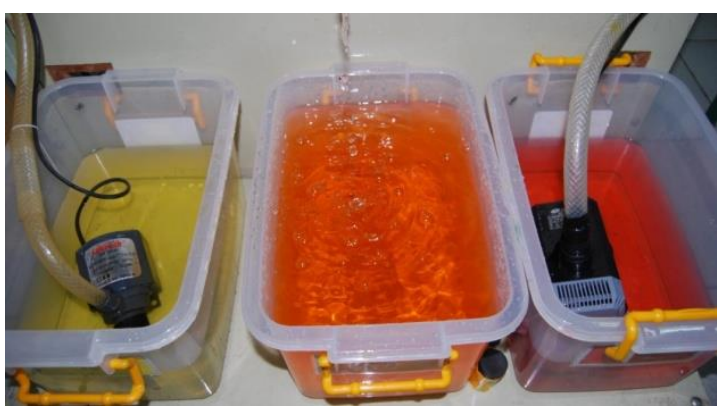

Gambar 27. Tangki Penyimpanan Hasil Akhir terisi penuh (tengah). 
Seminar Nasional Instrumentasi, Kontrol dan Otomasi (SNIKO) 2015

Bandung, Indonesia, 10-11 Desember 2015

Dengan kondisi relay solenoid valve (SV-3) ON pada Gambar 28.

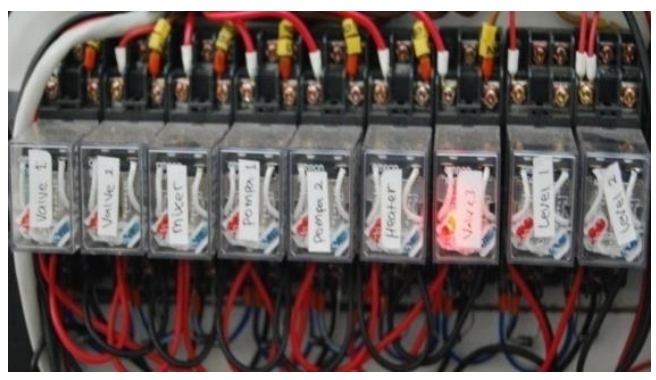

Gambar 28. Relay solenoid valve (SV-3) ON

\section{Simpulan}

Berdasarkan hasil yang diperoleh dari pengerjaan penelitian ini, dapat disimpulkan :
Simulator fluid-mixing yang dibangun memiliki harga yang lebih murah dengan pemilihan komponen-komponen yang mendukung.

Pencampuran bisa dilakukan untuk 2 jenis warna dengan jenis fluida yang sama yaitu air.

\section{Daftar Pustaka}

[1] [1] Hadisupadmo, Sutanto. Diktat Kuliah : Gambar Instrumentasi (P\&ID) dan Sistem Pneumatik \& Hidrauli. Depertemen Teknik Fisika. Institut Teknologi Bandung, 2011.

[2] [2] Periawan, Perancangan Dan Implementasi Simulator Flow Trainer Untuk Menentukan Karateristik Flow Metering Dengan Metode Obstruction, Tugas Akhir, Institut Teknologi Bandung, 2010.

[3] [3] Sloop, Paul.B.Zbar-Joseph, Dasar - Dasar Listrik dan Elektronika, Edisi ke Empat, SMK Negeri 1 Cimahi, 2009 